\title{
Acculturation of Sam Poo Kong Temple as a Cultural Unity in Semarang City (Study of History and Environment)
}

\author{
FS Aristyo Nugroho ${ }^{1}$, Muhammad Abdullah ${ }^{2}$ \\ ${ }^{1}$ Master of Literature Program, Diponegoro University, Semarang, Indonesia \\ ${ }^{2}$ Master of Literature Program, Diponegoro University, Semarang, Indonesia
}

\begin{abstract}
This environmental-based cultural learning is an attempt to represent the existing culture in Indonesia, especially in Semarang. The city of Semarang itself has witnessed the culture itself. This city has a building that has high historical and cultural value. The building is the Sam Poo Kong Temple. This historical and cultural building has become a symbol of tolerance between religious communities. In Indonesia there are often political issues that carry religion and race, however, above all that there is unity between religions and races as well. Through a coastal cultural event held in Sam Poo Kong with the arrival of cak Nun (April 18, 2019), it will make residents more concerned about unity and ignore the issues of division that exist. In practice the method follow the steps in stages as follows inventory and identification of acculturation of Sam Poo Kong temple and text compilation method, which is the collection of the best spoken text which will be used as the selected text with coastal communities theory. The conclusion is this coastal culture in Sam Poo Kong that will promote harmony, peace, and respect. This culture will fight against religion and ethnic issues that will harm this country.
\end{abstract}

\section{Introduction}

This This paper serves to provide the concept that the culture of Indonesian society has now undergone several changes. This change will be studied with an ecolinguistic perspective to learn based on the environment, social environment, humanity, and critical culture. Cultural developments and changes in the order of modern human life need to be examined, addressed, and re-evaluated in depth.

Life is constantly changing and developing towards a higher level, both culture and civilization. All also need a definite purpose and direction in reflection and evaluation. This environmental-based cultural learning is an attempt to represent the existing culture in Indonesia, especially in Semarang. Semarang is a city that is the capital of Central Java. The city of Semarang itself has witnessed the culture itself. This city has a building that has high historical and cultural value. The building is the Sam Poo Kong Temple.

This historical and cultural building has become a symbol of tolerance between religious communities with various ethnic groups and races. Diversity in Semarang society includes several aspects, both economic and socio-cultural aspects. Apart from the local Indonesian ethnicity in Semarang, foreign ethnicities live in Semarang with various religions. Each of

*Corresponding author: tyoknugroho45@gmail.com 
these ethnicities has a way of life and culture that differentiates it from other ethnicities. The foreign ethnic groups who came and settled in Semarang were Arab, Chinese (Chinese), Malay, and Indian. There are more Chinese ethnicities than other foreign ethnicities in Semarang, and they hold considerable influence in the economic and cultural fields.

Some historical writings show that in the 15th century during the Ming dynasty (13681643), Chinese people from Yunnan began to arrive to spread Islam, especially on the island of Java. It cannot be denied that Admiral Zheng He or Sam Poo Kong's voyages in 1410 and 1416 with the fleet he led landed on the coast of Simongan, Semarang. Apart from being a messenger of Emperor Yung Lo to visit the King of Majapahit, he also aimed to spread Islam. Admiral Zheng became one of the ethnic Chinese figures who also made history in the city of Semarang.

Semarang became an entire area for Zheng He shipping because Semarang was the most extended stopover when sailing in the archipelago due to the health problems that Wang Jihong experienced when he stopped in Semarang. Even Wang and Zheng He founded a place of worship known as the Sam Poo Kong Temple. Besides that, Zheng He's crew also decided to stay in the city of Semarang. Zheng He heritage cultures are very diverse, and their influence is decisive in Semarang; even though he comes from the Chinese community, this significant influence is because Zheng He is a Muslim (a minority group in China) but is influential in the Chinese empire, which Buddhism and Confucianism heavily influence.

The cultural influence and acculturation that exist due to Zheng He arrival in Semarang and after his crew named Wang Jinghong built the local community can accept the Sam Poo Kong Temple because of the pluralistic nature that exists in these cultural values, besides that the interaction also influences it both between the Chinese and indigenous communities, which may be attached to the identity of the city of Semarang.

In Indonesia, there are often political issues that carry religion and race; however, there is unity between religions and races. A coastal cultural event held in Sam Poo Kong with the arrival of cak Nun has brought back concern with unity and ignored the issues of division. It is this coastal culture in Sam Poo Kong that will promote harmony, peace, and respect. This culture will fight against ethnic and religious issues that will divide this country.

On April 18, 2019, Emha Ainun Najib, often called Cak Nun, returned to Semarang. The man came to invite people to learn about culture together at Sam Poo Kong Temple. Presenting the theme "The Role of Archipelago Culture as a Driving Force for the Creation of National Unity," Cak Nun not only gave a lecture but invited eight thousand spectators who were present to discuss and embraced several committees of the Sam Poo Kong Foundation at the Cultural Stage in front of Sam Poo Kong that night. Based on this background, the author determines the article's title "Acculturation of Sam Poo Kong Temple as a Cultural Unity in Semarang City".

\section{Material and Method}

\subsection{Coastal Communities}

In In the history of the arrival and spread of Islam in Indonesia, the word coastal area can never be ignored. This is because, as is well known, the history of the entry of Islam in Indonesia has always originated from fishing communities and traders, most of whom were concentrated in coastal areas around the Indonesian seas. This historical memory is still used as a definitive reference [1].

A coastal community is a community with the main characteristics of relying on their livelihoods from marine resources. Their means of production are usually boats, with a 
hierarchical economic system such as ship owners, go-betweens, laborers, and traditional fishers. However, in coastal communities who live in urban areas, besides going to the sea, they also farm, work in offices, businesses, etc.

Coastal is the meeting area between land and sea. Land direction includes parts of the land, both dry and submerged in water, which is still influenced by sea characteristics such as tides, sea breezes, and saltwater infiltration. Coastal communities are groups of people who live together in coastal areas to form and have a distinctive culture related to their dependence on the utilization of coastal resources. Theoretically, coastal communities live and carry out socio-economic activities related to resources in coastal areas and oceans. Thus, coastal communities have a high enough dependence on the potential and conditions of coastal and marine resources. However, coastal communities can also be broadly defined as people who live spatially in areas bordering the sea [2].

The striking difference in socioeconomic status between relatives cannot be a barrier to creating close social relations between them. Opportunities and socioeconomic development of coastal communities are: (a) emphasizing community-based and patterned management; and (b) good governance paradigm is applied. In addition, some people have begun to realize that the government assistance provided so far has been sourced from (foreign) loan funds, which of course, the people themselves have to bear the burden of repaying the loans. There is pride from these coastal communities if they can solve their problems to manage so that it shows financial results. In the implementation of development, these coastal communities have been able to act as supervisors and coordinate with related agencies for this success.

In practice, the description of the method can follow the steps in stages as follows:

1. Inventory and identification of acculturation of Sam Poo Kong temple.

2. The text compilation method is the collection of the best-spoken text used as the selected text.

\section{Discussion}

\subsection{Cultural Influence in the Acculturation of the Sam Poo Kong Temple}

This influence is divided into the influence of the architectural form of the Sam Poo Kong Temple and the influence of outside culture.

1. The architect of Sam Poo Kong Temple The Sam Poo Kong Temple area, which was once a sea has an area of 3.2 hectares; there are five building complexes. These five building complexes have a unique architecture in a combination of Chinese, Javanese, and Islamic architecture. The temple building is a feature of traditional Chinese architecture. Unlike the shape of a temple building in general, Sam Poo Kong Temple has its characteristics, namely with a unique building that combines traditional Chinese buildings with traditional Javanese buildings and a touch of Islamic elements (mosque buildings).

Elemental touches of the mosque include The Sam Poo Kong Temple building facing the Qibla. Unlike other temples in general, Sam Poo Kong Temple has a touch of green on the roof. In Islam, the green color is a symbol of the color of the clothes of the inhabitants of heaven. There is a large drum located inside the main building of the Sam Poo Kong Temple. However, Zheng He's fleet members are adherents of different religions, namely Islam, Buddhism, and Konghuchu. However, Admiral Zheng He adheres to Islam, so it is not surprising that Sam Poo Kong Temple has a touch of Islam.

Not only a touch of Islam, but the Sam Poo Kong Temple building is a combination of several buildings. Within the Sam Poo Kong Temple complex, there are several 
locations: main gate, pavilion, east gate, south gate, Zheng He statue area, Sam Poo Tay Djien Temple, Earth God Temple, Juru Mudi Temple, Jangkar Temple, and Tumpeng Tomb.

1. The influence of external culture in the acculturation of Sam Poo Kong Temple is from the religious side. As many sources explain that Zheng He is a Muslim, but on a voyage to explore the Asian region and the world, Zheng He also brought several priests from other religions developed in China. These priests also carry a mission to spread the religions and beliefs they profess, including Buddhism, Confucianism (Kong $\mathrm{Hu} \mathrm{Chu}$ ), Taoism, and Islam. There was a mixture of Buddhism, Kong $\mathrm{Hu}$ Chu, and Tao in its development, which were later called Tri Dharma followers. This group is significantly developed in Semarang. Many Tri Dharma priests say that this teaching is original from China which was initially brought into Semarang thanks to Zheng He's services.

Zheng He himself also spread his religion, namely Islam. So that here it gave rise to pluralism which was quite influential, which Zheng He and his crew brought. Zheng He also taught the natives the ways to honor ancestral spirits; thus, even though Zheng $\mathrm{He}$ was a Muslim, he could not let go of the cultural elements of Chinese society. Before the end of the New Order, activities related to Chinese religion were strictly prohibited because Semarang Chinese carried out various religious activities in private. In its development after the New Order era ended in 1998, religious activities began to open up, and the Tri Dharma Semarang community played an essential role in preserving Zheng He heritage cultures in Semarang. Even for Tri Dharma followers, Zheng He was made a Kongco (an elder who is considered to be a god) so that many Tri Dharma followers worship Zheng He.

In today's development, the preservation of Zheng He's cultural heritage also involves the Semarang Chinese Muslim Association; this is based on the fact that Zheng He is a Muslim. For Chinese people in Semarang and Javanese who have the Javanese belief (a mixture of Islam and Javanese culture), Zheng He is also considered an exceptional person in spreading religion.

Apart from the religious (religious) point of view, Zheng He also left a historical place. The k-5 layout of the building runs from north to south. Earth God Temple is known as Te Ti Kong, the place for worshiping the God of Earth Temple for those who expect blessings from Earth God Te Ti Kong. Tomb of Juru Mudi This tomb is the tomb of Wang Jinghong, one of Zheng He's confidants, who died in Gedong Batu. This place is often visited by people who want to be successful in business. Juru Mudi is also known as Dampo Awang. This building contains a large tree that is 600 years old. If you look carefully, the old tree branch hugs the roof of the Kyai Juru Mudi tomb building. Sam Poo Kong Cave is inside the main building of Sam Poo Kong Temple. It is said that this magnificent building was a mosque used to worship Zheng He and his crew. Inside the temple, there is a drum; for moslems, it conveys the message that it is time for prayer. Behind the temple is a building with walls filled with reliefs that tell of Zheng He's arrival in Semarang. Between the walls, there is a cave passage that is often used for prayer and reading fortunes (Djiamsie). Inside the cave, there is an altar, fortune telling tools, a small statue of Zheng He covered in gold weighing 50 grams, and a well whose water is believed to cure all kinds of ailments. Before the renovation in 2002, this temple had an area of $16 \times 16$ meters; now, it is $34 \times 34$ meters.

In Gedong Batu, Semarang, the August 17 prayer was held. This is proof that independence day has been a big day for indigenous people and Chinese descendants in 
Indonesia since 1945. Apart from these prayers, at Sam Poo Kong Temple, prayers are held every 1st (Djee It) and every 15th (Tjap Go). Among the prayers, the most crowded is the Sam Poo Gia Hio prayer because it is related to the day of Sam Poo Kong's arrival in Gedong Batu, Semarang. The existence of a community of citizens of Chinese descent in Semarang The interaction between the general public of Semarang and the community of Chinese citizens of Semarang in various fields is the creation of social life in society. One of the prominent interactions is in the cultural field. This, of course, is based on the same conception of achieving high social values, namely the value of peace and harmony. The similarity of concepts achieved by both parties influenced the majority ethnic group in Semarang in understanding the revival of Chinese culture. For the sake of assimilation created in the era of freedom, Chinese cultures became treasures to reproduce Indonesian culture. This can give a positive response to the revival of Chinese culture and the message contained in it.

\subsection{Ways of Cultural Fighters to Embrace Diverse Populations in the City of Semarang as a Means of Unity and Against SARA Issues}

Thursday, April 18, 2019, the Central Java Regional Police and regional cultural observers collaborated in forming a da'wah and discussion event with the title "Learn Together with Cak Nun, Kiai Kanjeng with the Central Java Police." Cak Nun's discussion was not far from the values of life as citizens, religious people, and humans who do not differentiate. Parts of the event that are key in uniting the community:

Say hello to people of different religions and beliefs. Responded with any greeting Assalamualaikum is valid. For example, Assalamualaikum to Confucian brothers answered by Wei De Dong Tian, and vice versa.

Cak Nun also invited us to never blame others based on their identity. Right and wrong are not because the person's religion is Islam, Christianity, Buddhism, Catholicism, or any other religion. "What is wrong is his behavior. So when people make mistakes, do not be labeled because of their religion, because of their ethnicity, because of their families, and others, what is wrong is their behavior," said Cak Nun.

Human affairs in the world will be in order if we do not make three bad things: killing, stealing, and insulting. Corruption is included as stealing, bullying is considered an act of insult, and murder, intentionally or unintentionally, can come from bullying and theft. When we avoid these three evil actions, then mindfulness will be achieved.

Resistance to politics in the name of religion can be done with this interfaith tolerance. Tolerance between religions will bring social life to a higher level. Personal religion should be contemplated in the heart of every individual, not as a means of dividing parties in politics. Religious tolerance will always be a shield to overcome "hoaxes" that often occur through social media and destructive activities.

Cak Nun also invited several volunteers from VIP guests on stage to give gifts to the audience who could answer questions about the history of the Sam Poo Kong temple. Various questions regarding the Islamic name Cheng Ho, the meaning of eunuchs, the Chinese community in Java, Cheng Ho's visit to the palace, Cheng Ho, were castrated. Cak Nun also emphasized that to make corruptors obey the state by being castrated because ancient eunuchs were castrated to obey their emperor. According to the author, these questions are Cak Nun's way of reminding us that as Indonesian citizens, we must continue to maintain the history that our predecessors have fought for and continue to maintain the existing culture.

The event that night also performed several coastal cultures in Semarang, namely Gamelan Kiai Kanjeng, which accompanied the performance of Cak Nun, the song of Gambang Semarang, Prau Layar, and other songs accompanied by jogging. These various dances are also described cak nun. Some of the jogs described are dancing to show prayers 
for God, joy, and tones that also arouse someone's lust according to the rhythm. The cultures that are brought are the coastal culture of Semarang, which is sometimes forgotten in the hustle and bustle of modern culture.

Cak Nun closed the event by playing the song "Sayang," sung by dozens of orphans who were invited to go on stage with the Sam Poo Kong Foundation leaders. Prayers are also offered after chanting. The Sam Poo Kong Foundation leader, Mulyadi Setiakusuma, was very grateful for holding the event. He did not want this temple to be a place of worship only, but rather a place of historical tourism. "We are proud to be able to bring thousands of people here. Hopefully, the Sam Poo Kong Temple will continue to provide benefits to all people." This sentence closes the discussion of this paper. The city of Semarang is very rich in culture and a variety of religions. We, as candidates for master's degrees in literature, should be able to participate in organizing and enlivening these cultural events.

\section{Conclusion}

Semarang became an entire area for Zheng He shipping because Semarang was the most extended stopover when sailing in the archipelago due to the health problems that Wang Jihong experienced when he stopped in Semarang. Even Wang and Zheng He founded a place of worship known as the Sam Poo Kong Temple. Besides that, Zheng He's crew also decided to stay in the city of Semarang. Zheng He heritage cultures are very diverse, and their influence is decisive in Semarang; even though he comes from the Chinese community, this significant influence is because Zheng He is a Muslim (a minority group in China) but is influential in the Chinese empire, which Buddhism and Confucianism heavily influence.

The cultural influence and acculturation that exist due to Zheng He's arrival in Semarang and after his crew named Wang Jinghong built the local community can accept the Sam Poo Kong Temple because of the pluralistic nature that exists in these cultural values, besides that the interaction also influences it both between the Chinese and indigenous communities, which may be attached to the identity of the city of Semarang.

Supported by an event held by the Central Java Regional Police with Cak Nun, the diversity of coastal cultures in Semarang was displayed in the event. The da'wah program and discussion entitled "Learn Together with Cak Nun, Kiai Kanjeng with Polda Central Java." The discussion that Cak Nun brought was not far from the values of life as citizens, religious people, and humans who do not differentiate. Resistance to politics in the name of religion can be done with this interfaith tolerance. Tolerance between religions will bring social life to a higher level. Personal religion should be contemplated in the heart of every individual, not as a means of dividing parties in politics. Religious tolerance will always be a shield to overcome "hoaxes" that often occur through social media and activities that divide the nation. It was a part of the event that was the key to unifying the community.

\section{Referance}

1. Kusnadi. Nelayan: Strategi Adaptasi dan Jaringan Sosial (2000)

2. Takari, Muhammad. Peranan Peradaban Masyarakat Pesisir dalam Era Globalisasi (2017)

3. Afan, Faisal. "Dakwah di Klenteng Sam Poo Kong Semarang, Cak Nun: Kalau Ada Koruptor Perlu Dikebiri”, tribunjaeng.com (April 19, 2019) https://jateng.tribunnews.com/2019/04/19/dakwah-di-klenteng-sam-poo-kongsemarang-cak-nun-kalau-ada-koruptor-perlu-dikebiri

4. Budiman, Amien. Semarang Riwayatmu Dulu (1978)

5. Coppel, Charles A. Tionghoa dalam Krisis. (1994) 
6. Effendy, Usman. Laksamana Haji Zheng He Berlayar ke Indonesia sebagai Negarawan dan Mubaligh (1987)

7. Hidayat, Z. M. Masyarakat dan Kebudayaan Cina Indonesia (1977)

8. Hidayatullah, Ahamad Fauzan. Laksamana Zheng He dan Kelenteng Sam Poo Kong, Spirit Pluralisme dan Akulturasi Kebudayaan (2005)

9. Huda, Rivai Anas Amirul. "Makalah Akulturasi Kelenteng Sam Poo Kong", slideshare.net $\quad$ (May 21, 2017) https/www.slideshare.net/RivaiAnasAmirulHuda/makalah-akulturasi-kelenteng-sampoo-kong-semarang

10. Yuanzhi, Kong. Moslem Tionghoa Zheng He (2000) 